\title{
Short-Term Administration of Alibernet Red Wine Extract Failed To Affect Blood Pressure and To Improve Endothelial Function in Young Normotensive and Spontaneously Hypertensive Rats
}

\author{
P. BALIŠ ${ }^{1}$, A. PÚZSEROVÁ ${ }^{1}$, P. SLEZÁK ${ }^{1}$, N. ŠESTÁKOVÁ ${ }^{1}$, O. PECHÁŇOVÁ ${ }^{1}$, \\ I. BERNÁTOVÁ ${ }^{1}$ \\ ${ }^{1}$ Institute of Normal and Pathological Physiology, Centre of Excellence for Examination of \\ Regulatory Role of Nitric Oxide in Civilisation Diseases, Slovak Academy of Sciences, Bratislava, \\ Slovak Republic
}

Received December 7, 2012

Accepted February 12, 2013

On-line July 17, 2013

\begin{abstract}
Summary
As wine polyphenols were shown to possess many positive effects in mammals, including improvement of vascular function, this study investigated the effect of the Slovak Alibernet red wine extract (AWE) on blood pressure and vascular function in young normotensive Wistar-Kyoto (WKY) and spontaneously hypertensive (SHR) rats. Six weeks old, male, WKY and SHR were treated with AWE for three weeks at the dose of $24.2 \mathrm{mg} / \mathrm{kg} /$ day. Blood pressure (BP), determined by tail-cuff plethysmography, was significantly elevated in SHR vs. WKY and AWE failed to affect it. Lipid peroxidation was evaluated by determination of thiobarbituric acid-reactive substances. Vascular function was assessed in rings of the femoral artery using Mulvany-Halpern's myograph. Maximal endothelium-dependent acetylcholine (ACh)-induced relaxation was reduced in control SHR vs. WKY rats by approximately $9.3 \%$, which was associated with a significant decrease of its NO-independent component. AWE failed to affect maximal ACh-induced relaxation, both its NO-dependent and independent components, compared to controls of the same genotype. AWE however reduced lipid peroxidation in the left ventricle of both WKY and SHR and in the liver of SHR. In conclusion, three-week administration of AWE failed to reduce BP and to improve endothelial function in the femoral arteries of both genotypes investigated.
\end{abstract}

\section{Key words}

Antioxidant • Blood pressure • Endothelial function • Nitric oxide

- Red wine polyphenols

\section{Corresponding author}

Iveta Bernátová, Institute of Normal and Pathological Physiology, Slovak Academy of Sciences, Sienkiewiczova 1, 81371 Bratislava, Slovak Republic. Fax: +421-2-52968516. E-mail: Iveta.Bernatova@savba.sk

\section{Introduction}

Natural polyphenols are a wide group of substances produced in secondary metabolism of plants. Depending on the chemical structure, they are divided into several subgroups (Ramassamy 2006), such as phenolic acids, non-flavonoid polyphenols and flavonoids. The positive influence of natural polyphenols on human health was suggested about twenty years ago as a possible explanation of the French paradox (Hertog et al. 1995). Nowadays, there is epidemiological evidence that moderate consumption of food and drinks rich in natural polyphenols, including red wine, is beneficial to human health (Pilšáková et al. 2010).

Several studies reported that consumption of red wine was associated with lower incidence of cardiovascular diseases (Carollo et al. 2007, Costanzo et al. 2011). Additionally, treatment with either red wine (RW) or other dietary sources, as e.g. purple grape juice, were found to reduce the susceptibility of LDL to oxidation and to improve endothelium-dependent vasodilatation in patients with coronary heart disease (Stein et al. 1999). As to blood pressure, dealcoholized

PHYSIOLOGICAL RESEARCH • ISSN 0862-8408 (print) • ISSN 1802-9973 (online)

(c) 2013 Institute of Physiology v.v.i., Academy of Sciences of the Czech Republic, Prague, Czech Republic

Fax +420 241062 164, e-mail: physres@biomed.cas.cz,www.biomed.cas.cz/physiolres 
red wine reduced both systolic and diastolic blood pressure (BP) in subjects at high cardiovascular risk (Chiva-Blanch et al. 2012). Hypertensive subjects who were moderate wine drinkers had a significantly lower risk of death from all causes than had abstainers (Renaud et al. 2004).

The mechanisms involved in beneficial effects of natural polyphenols include reduction of platelet aggregation (Demrow et al. 1995), increased HDL concentration (Bornhoeft et al. 2012), reduced LDL oxidation and concentration (Nigdikar et al. 1998, Agouni et al. 2009, Bornhoeft et al. 2012), and improvement of antioxidant defense system (Scola et al. 2010, Lionetto et al. 2011). Besides antioxidant properties, which play a significant role in cardioprotection, red wine polyphenols affect vascular function via modulation of nitric oxide (NO) bioavailability. Improved vascular function was shown in several experimental models of human diseases after administration of either red wine or its constituents. Red wine compounds (RWC) prevented metabolic and cardiovascular alterations in obese rats (Agouni et al. 2009), improved flow-mediated dilatation and plasma NO level in hypercholesterolemic rabbits (Zou et al. 2003), and restored endothelial function in deoxycorticosterone acetate-salt hypertensive rats (Jiménez et al. 2007).

In our previous experiments, red wine polyphenolic compounds were shown to prevent excessive increase of BP in rats exposed to simultaneous administration of L-NAME, a well known NO synthase inhibitor (Pechánová et al. 2004). In rats with fully developed NO-deficient hypertension, administration of RWC (after cessation of L- NAME treatment) produced a greater readiness to blood pressure decrease than did spontaneous recovery and was associated with improvement of endothelial function and NO production (Bernátová et al. 2002). Additionally, estrogen receptor alpha has been identified as a key target of RWC on the endothelium (Chalopin et al. 2010).

Regarding the positive effects of red wine, some studies related them to alcohol itself rather than to its non-alcoholic components (Hansen et al. 2005). Other studies failed to find antihypertensive effects of red wine or RWC (Retterstol et al. 2005, Andrade et al. 2009). It is important to mention that the polyphenolic content of red wine depends on many factors, including grape variety, provenance and process of vinification (Sato et al. 1996). Thus the effect of different red wines on the human and animal organism might be variable.
Despite extensive research, relatively little information is available on the vascular effects of red wine and RWC in spontaneously hypertensive rats, an experimental model of human essential hypertension (Pintérová et al. 2011). Previously we found elevated NO production in the aorta and left ventricle of SHR rats treated with alcohol-free extract from Alibernet red wine produced in the region of Modra, Slovak Republic (Kondrashov et al. 2012). The aim of the present study was to investigate the effect of the same alcohol-free extract from Alibernet red wine on blood pressure and vascular function in young normotensive and spontaneously hypertensive rats.

\section{Methods}

Animals

All rats used in the study ( $n=6$ in each group) were born in our certified animal facility in order to maintain the same environmental background of all animals. All rats were housed at $22-24{ }^{\circ} \mathrm{C}$ on a $12: 12-\mathrm{h}$ dark-light cycle (lights on from $06.00 \mathrm{~h}$ till $18.00 \mathrm{~h}$ ) and maintained on a standard pellet diet and tap water or nonalcoholic solution of Alibernet red wine extract (AWE) ad libitum. All procedures were used in accordance with the institutional guidelines and they were approved by the State Veterinary and Food Administration of the Slovak Republic.

At the beginning of the experiment, 6-week-old male normotensive Wistar-Kyoto rats (WKY) and spontaneously hypertensive rats (SHR) were randomly divided into the control group and the group treated with AWE for 3 weeks. The animals were kept in groups of three per cage $(35 / 55 / 20 \mathrm{~cm})$. AWE was diluted in tap water in the final dose of $24.2 \mathrm{mg} / \mathrm{kg}$ /day (Kondrashov et al. 2012). AWE was administered to rats in the appropriate daily volume of water, assessed for each rat one week before onset of the experiment.

AWE was prepared from Alibernet red wine obtained from the Slovak State Institute of Viniculture, Modra, Slovak Republic. AWE was prepared in the evaporative condenser as described previously (Kondrashov et al. 2012). Wine was subjected to the process of dealcoholization and concentration, resulting in alcohol-free concentrated wine extract. The total phenolic content of AWE was $24172 \mathrm{mg} / \mathrm{l}$ of gallic acid equivalents (Kondrashov et al. 2012). After concentration, AWE was kept in the refrigerator at $4{ }^{\circ} \mathrm{C}$. 


\section{Blood pressure and basic cardiovascular parameters}

Blood pressure was determined non-invasively on the tail of the rats as described previously (Puzserova et al. 2013). Briefly, one week before experiment, the rats were handled and accustomed to the tail-cuff procedure. Blood pressure was further determined before experiment (basal) and at the 1st, 2nd and 3rd week of experiment. Body weight (BW) was recorded on the same days. At the end of experiment, the rats were killed by decapitation after a brief $\mathrm{CO}_{2}$ anesthesia. Wet weight of the left heart ventricle (LVW) as well as the tibial length (TL) were determined.

\section{Oxidative stress markers - TBARS}

Thiobarbituric acid-reactive substances (TBARS), a marker of lipid peroxidation, were measured as described by $\mathrm{Hu}$ et al. (1989), with some modifications. To determine TBARS, $1 \mathrm{ml}$ of tissue homogenate of the left ventricle and liver $(10 \%, \mathrm{w} / \mathrm{v})$ was added to $2 \mathrm{ml}$ of $7.5 \%$ trichloroacetic acid and mixed. After centrifugation at $1000 \mathrm{~g}$ for $10 \mathrm{~min}, 1 \mathrm{ml}$ of the supernatant was added to $0.5 \mathrm{ml}$ of $0.7 \% 2$ thiobarbituric acid and heated in a water bath at $100{ }^{\circ} \mathrm{C}$ for $10 \mathrm{~min}$. After cooling, the TBARS were measured at $532 \mathrm{~nm}$. An extinction coefficient of $156000 \mathrm{~mol}^{-1} 1$ $\mathrm{cm}^{-1}$ was used for calculation of results.

\section{Determination of vascular reactivity}

Vascular function was determined in the femoral arteries as described previously (Puzserova et al. 2013). The segments of the arteries (approximately 1.28 \pm 0.03 $\mathrm{mm}$ long) were mounted as ring-shaped preparations in the Mulvany-Halpern's style small vessel wire myograph (Mulvany and Halpern 1977) chamber (Dual Wire Myograph System 410A, DMT A/S, Aarhus, Denmark).

The experimental protocol consisted of the following steps: (1) Arteries were pre-constricted by serotonin (Ser, $1 \mu \mathrm{mol} / \mathrm{l}$ ). When the contraction of the artery was steady, increasing concentrations of the endothelium-dependent vasodilator acetylcholine (ACh, from 0.001 to $10 \mu \mathrm{mol} / \mathrm{l})$ were added in cumulative manner. (2) The same experiment was repeated after $25 \mathrm{~min}$ pre-incubation with the nitric oxide synthase inhibitor $\mathrm{N}^{\mathrm{G}}$-nitro-L-arginine methyl ester (L-NAME, $300 \mu \mathrm{mol} / \mathrm{l}$ ) in the bath medium. (3) Finally, after Ser pre-constriction $(1 \mu \mathrm{mol} / \mathrm{l})$, the nitric oxide donor sodium nitroprusside (SNP, 0.001 to $10 \mu \mathrm{mol} / \mathrm{l}$ ) was cumulatively added and the endothelium-independent relaxation response curve was recorded. The artery was four times washed out with modified physiological salt solution (composition in mmol/l: $\mathrm{NaCl} 118.99, \mathrm{KCl} 4.69$, $\mathrm{NaHCO}_{3} \quad 25, \quad \mathrm{MgSO}_{4} .7 \mathrm{H}_{2} \mathrm{O} \quad 1.17, \mathrm{KH}_{2} \mathrm{PO}_{4} \quad 1.18$, $\mathrm{CaCl}_{2} .2 \mathrm{H}_{2} \mathrm{O} 2.5, \mathrm{Na}_{2}$ EDTA 0.03 and glucose 5.5) and stabilized for $20 \mathrm{~min}$ after each step (Puzserova et al. 2013).

The extent of relaxation was expressed as the percentage of serotonin-induced precontraction. NOdependent (i.e. L-NAME-sensitive) and NO-independent (i.e. L-NAME-resistant) components of ACh-induced relaxation were expressed as the area under the curve (AUC) in arbitrary units (au) calculated from individual dose-response curves. The NO-dependent component of endothelium-dependent relaxation was calculated as the difference of the AUC between ACh-induced relaxation before and after L-NAME pretreatment.

Resting wall tension (basal tension), which arises from the properties of the passive elements in the vascular wall, and normalized diameter were determined after the normalization procedure as described previously (Mulvany and Halpern 1977).

All the chemicals used in this study were purchased from Sigma-Aldrich (Germany). All drugs were dissolved in distilled water and concentrations are expressed as final concentration in the myograph chamber.

\section{Statistical analysis}

Data are presented as group mean values \pm S.E.M. of the number (n) of observations. Results were analyzed by analysis of variance (ANOVA). One-way ANOVA was used where appropriate. In case of significant results pairwise comparison with Bonferroni adjustment was employed. Concentration response curves and blood pressure were compared using two-way ANOVA, followed by vertical contrast with Bonferroni adjustment. To assess depression present at high concentration of ACh-cumulative concentration response curves, the maximal response and the response at higher ACh concentration at a particular response curve were compared with Dunnet's test (see Fig. 3). Means were considered to differ significantly when $\mathrm{p}<0.05$.

\section{Results}

\section{Basic biometric and cardiovascular parameters}

The respective basal blood pressure of control WKY, AWE-treated WKY (WKYA), control SHR, and AWE-treated SHR (SHRA) was $98 \pm 5 \mathrm{~mm} \mathrm{Hg}$, 
$97 \pm 5 \mathrm{~mm} \mathrm{Hg}, 118 \pm 9 \mathrm{~mm} \mathrm{Hg}(\mathrm{p}<0.05$ vs. WKY $)$, and $119 \pm 2 \mathrm{~mm} \mathrm{Hg}(\mathrm{p}<0.05$ vs. WKYA $)$. AWE-treatment failed to alter BP vs. the respective control in either genotype investigated (Fig. 1).

Final BW and TL were significantly lower in both SHR groups vs. the respective WKY group (Table 1). Relative LVW was significantly increased in the SHR compared to WKY. AWE-treatment failed to affect these parameters, as compared to the control group of the same genotype (Table 1).

Table 1. Basic biometric and vascular parameters of the femoral artery of Wistar-Kyoto (WKY) and spontaneously hypertensive (SHR) rats.

\begin{tabular}{lcccc}
\hline & \multicolumn{2}{c}{ WKY } & \multicolumn{2}{c}{ SHR } \\
& Control (n=6) & AWE (n=6) & Control (n=6) & AWE (n=6) \\
\hline Final $B W(g)$ & $249 \pm 5$ & $253 \pm 5$ & $211 \pm 5^{\mathrm{x}}$ & $216 \pm 4^{+}$ \\
TL $(\mathrm{mm})$ & $36.2 \pm 0.2$ & $36.0 \pm 0.6$ & $31.4 \pm 1.2^{\mathrm{x}}$ & $33.1 \pm 0.9^{+}$ \\
$L V W / T L(\mathrm{mg} / \mathrm{mm})$ & $12.1 \pm 0.2$ & $12.8 \pm 0.8$ & $14.1 \pm 0.2^{\mathrm{x}}$ & $14.4 \pm 0.3^{+}$ \\
\hline ND $(\mu \mathrm{m})$ & $694 \pm 17$ & $683 \pm 23$ & $649 \pm 22$ & $612 \pm 14^{+}$ \\
$R W T(\mathrm{mN} / \mathrm{mm})$ & $0.76 \pm 0.10$ & $0.74 \pm 0.13$ & $0.85 \pm 0.11$ & $0.59 \pm 0.06$ \\
Ser $(\mathrm{mN} / \mathrm{mm})$ & $7.06 \pm 0.59$ & $7.33 \pm 0.49$ & $6.64 \pm 0.46$ & $7.16 \pm 0.36$ \\
$E_{\max A C h}(\%)$ & $83.52 \pm 2.15$ & $75.95 \pm 2.86$ & $75.75 \pm 2.38^{\mathrm{x}}$ & $71.04 \pm 4.66$ \\
$E_{\max L-N A M E}(\%)$ & $59.25 \pm 2.86^{\dagger}$ & $53.47 \pm 6.53^{\dagger}$ & $47.40 \pm 4.26^{\mathrm{x}}$ & $40.31 \pm 6.74^{\dagger}$ \\
$E_{\max S N P(\%)}$ & $96.8 \pm 0.7$ & $97.7 \pm 0.7$ & $96.8 \pm 1.3$ & $94.9 \pm 2.2$ \\
\hline
\end{tabular}

The final age of rats was 9 weeks. The concentration of serotonin was $1 \mu \mathrm{mol} / \mathrm{l}$. AWE - Alibernet red wine extract; BW - body weight; $E_{\max A C h}$ - maximal acetylcholine-induced relaxation; $E_{\max L-N A M E}$ - maximal acetylcholine-induced relaxation after L-NAME; $E_{\max S N P}-$ maximal sodium nitroprusside-induced relaxation; L-NAME - $\mathrm{N}^{\mathrm{G}}$-nitro-L-arginine methyl ester; LVW - left heart ventricle weight; ND normalized diameter of the femoral artery at $13.3 \mathrm{kPa}$; RWT - resting wall tension; Ser - vascular constriction induced by serotonin; TL - tibia length. Results are mean \pm S.E.M. ${ }^{x} p<0.05$ compared to WKY control, ${ }^{+} p<0.05$ compared to AWE-treated WKY, ${ }^{\dagger} p<0.05$ compared to the respective value before L-NAME

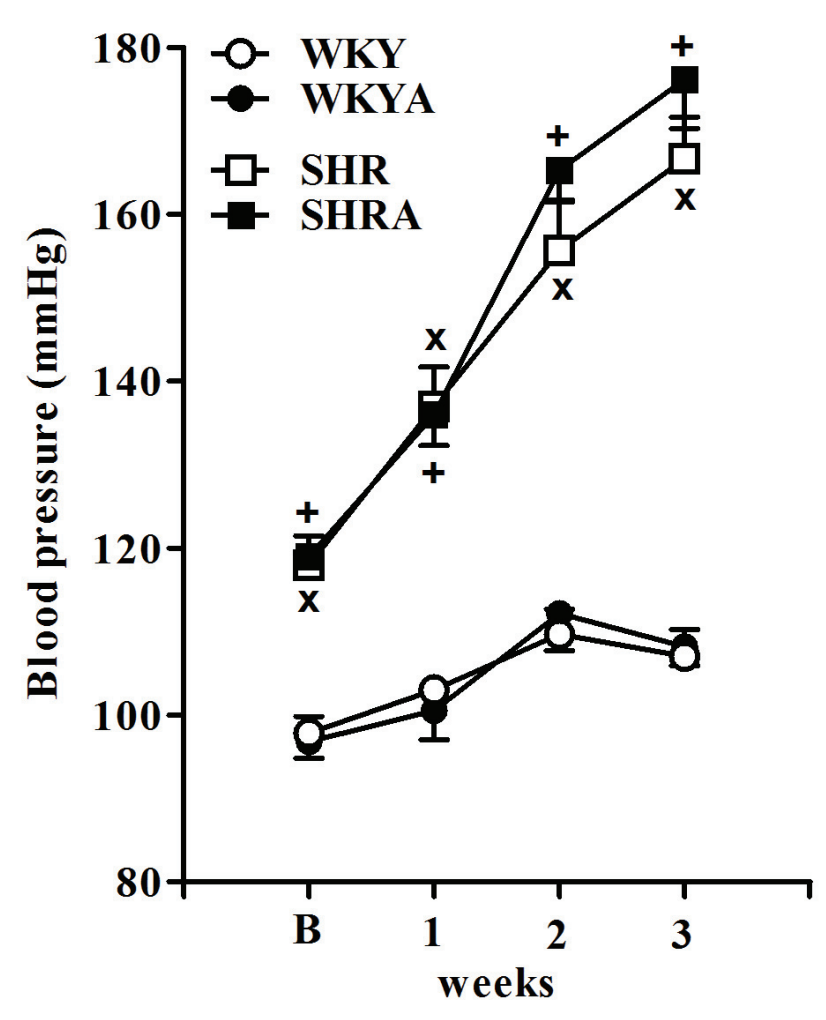

\section{TBARS}

AWE treatment led to significant reduction of TBARS in the left ventricle of both WKY and SHR. In the liver, the reduction of TBARS was seen only in SHR (Fig. 2).

\section{Vascular function}

There were no differences in the normalized internal diameter (ND) and resting wall tension of the femoral artery between control WKY and SHR. AWE reduced ND in SHR vs. WKYA (Table 1). AWE treatment failed to induce significant alterations either in serotonin-induced contraction or in maximal AChinduced relaxation $\left(\mathrm{E}_{\max }\right)$ before and after L-NAME $\left(\mathrm{E}_{\operatorname{max~L-NAME}}\right)$ administration.

Fig. 1. Effect of AWE on blood pressure of Wistar-Kyoto (WKY) and spontaneously hypertensive (SHR) rats. AWE - Alibernet red wine extract; B - basal blood pressure; WKYA, SHRA - rats treated with Alibernet red wine extract. Results are mean \pm S.E.M. of $n=6$ rats. ${ }^{x} p<0.05$ compared to control WKY group, ${ }^{+} p<0.05$ compared to AWE-treated WKY 


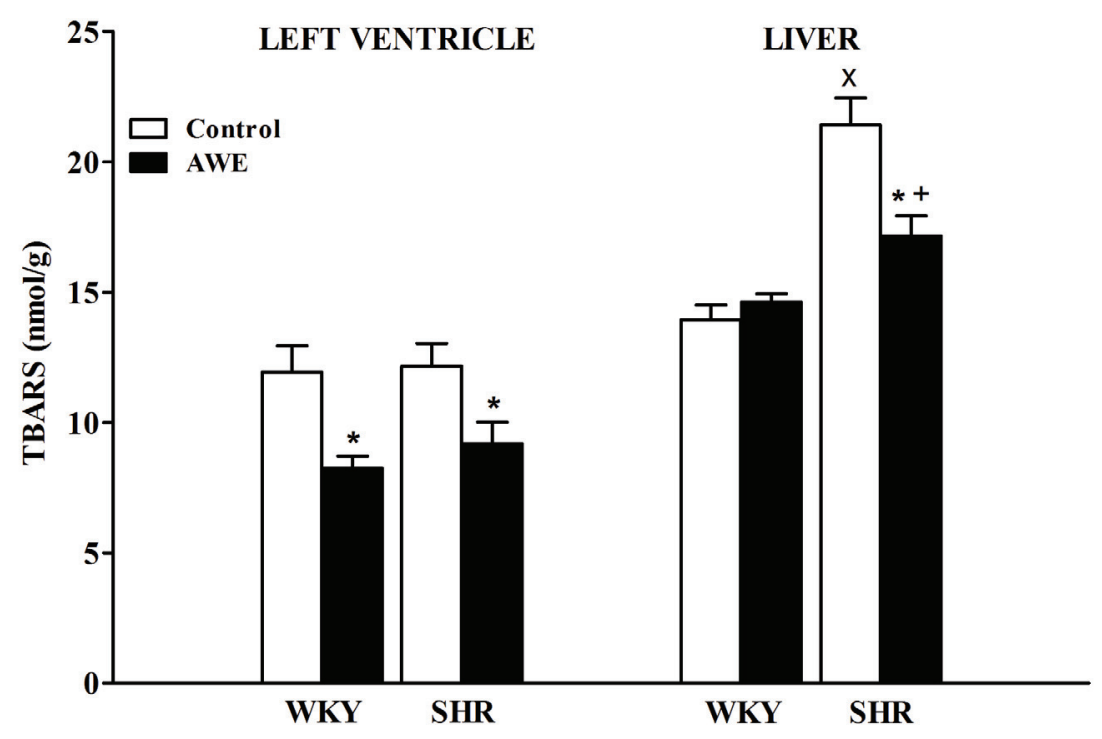

Fig. 2. Influence of AWE on oxidative status of Wistar-Kyoto (WKY) and spontaneously hypertensive (SHR) rats. AWE - Alibernet red wine extract; TBARS - thiobarbituric acidreactive substances. Values represent mean \pm S.E.M. of $n=6$ rats. $* p<0.05$ compared to the respective control group, ${ }^{x} p<0.05$ compared to WKY control, ${ }^{+} p<0.05$ compared to AWEtreated WKY
Maximal endothelium-dependent relaxation (calculated from individual dose-response curves) of the femoral artery was reduced in control SHR vs. control WKY (Table 1). However, higher concentrations of ACh (greater than $0.3 \mu \mathrm{mol} / \mathrm{l}$ ) led to contractions in SHR, resulting in reduced relaxation as compared to lower ACh concentration (Fig. 3B, D). There was also a significant decrease of total relaxation response in SHR vs. WKY when calculated as area under the curve $(313.49 \pm 13.87$ au vs. 359.15 $\pm 21.02 \mathrm{au}, \mathrm{p}<0.05)$.

Acute blockade of NO synthesis by L-NAME (300 $\mu \mathrm{mol} / \mathrm{l})$ reduced significantly vasorelaxation in all groups investigated compared to the respective value without L-NAME (Fig. 3C, D). AWE had no effect on endothelium-independent sodium nitroprusside-induced relaxation of the femoral artery in either genotype investigated (Fig. 3E, F).

The NO-dependent (i.e. L-NAME-sensitive) component of relaxation was similar in the control WKY and SHR group and AWE failed to affect it significantly, as compared to the control group of the same genotype (Fig. 4). However, the NO-dependent component of relaxation was increased significantly in AWE-treated SHR vs. AWE-treated WKY.

NO-independent (i.e. L-NAME-resistant) relaxation was reduced in the control SHR group vs. WKY and AWE did not improve it (Fig. 4).

\section{Discussion}

This study investigated the effect of a nonalcoholic extract from the Slovak Alibernet red wine on blood pressure and vascular function in young normotensive and spontaneously hypertensive rats. Three-week treatment of rats with AWE had no effect on blood pressure and ACh-induced relaxation of rats, regardless their genotype. However, AWE reduced lipid peroxidation in the left ventricle of both WKY and SHR, as well as in the liver of SHR.

As mentioned above, red wine and its constituents may affect the cardiovascular system via several mechanisms. First of all, RWC possesses significant antioxidant properties resulting from both direct scavenging of free radicals and modulation of the antioxidant defense system. In humans, superoxide dismutase (SOD), catalase (CAT), glutathione peroxidase (GPx) and glutathione reductase (GR) activities were elevated in blood after repeated red wine consumption (Fernández-Pachón et al. 2009, Noguer et al. 2012). Resveratrol, an antioxidant found in grapes and wine, was shown to increase the gene expression of SOD and GPX and to suppress the expression of pro-oxidative NADPH oxidase in human endothelial cells (Spanier et al. 2009). In diabetic rats, RWC prevented the decrease of antioxidant enzymes (SOD, CAT and GPx) and lipid peroxidation in the heart and liver (Udayakumar et al. 2010). As mentioned above, we showed recently that AWE, as used in this study, increased SOD activity but not expression in the left heart ventricle in SHR, while no changes were observed in WKY (Kondrashov et al. 2012). Interestingly, in this study we found reduced lipid peroxidation in the left ventricle of both WKY and SHR and in the liver of SHR. Similarly, the antioxidant capacity of various red wines correlated with the reduction of lipid peroxidation in the liver, kidney and lung of Wistar rats, without affecting CAT, SOD and 
A

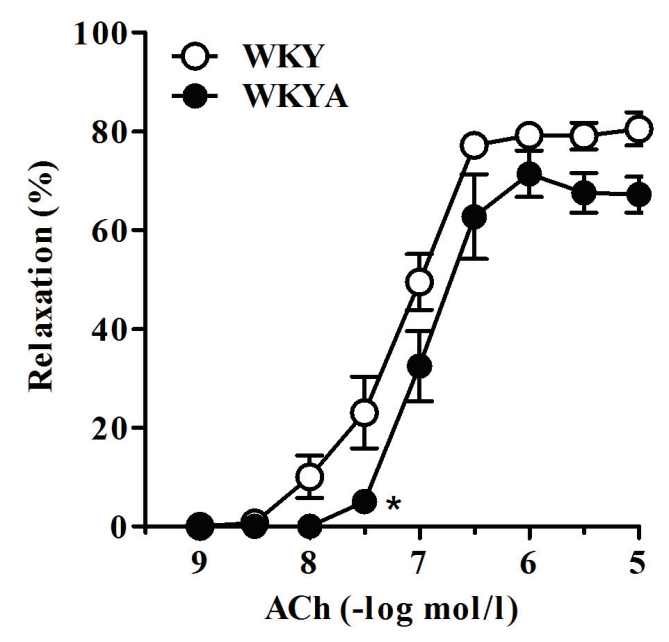

C

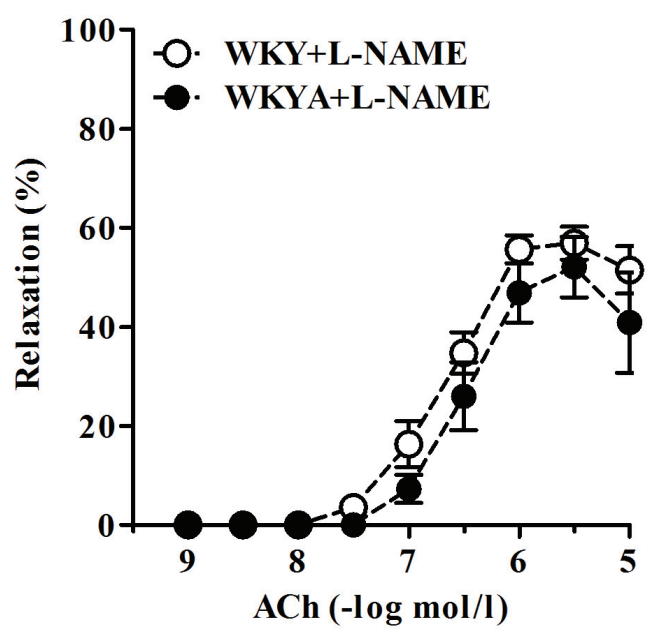

E

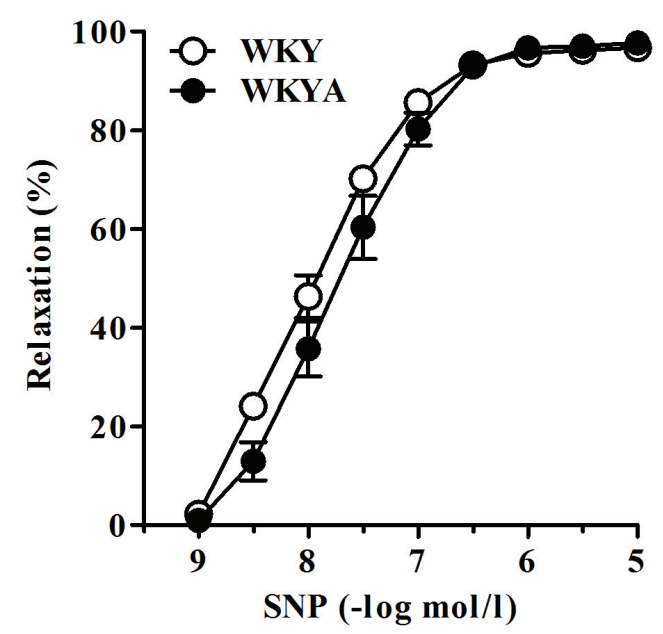

B

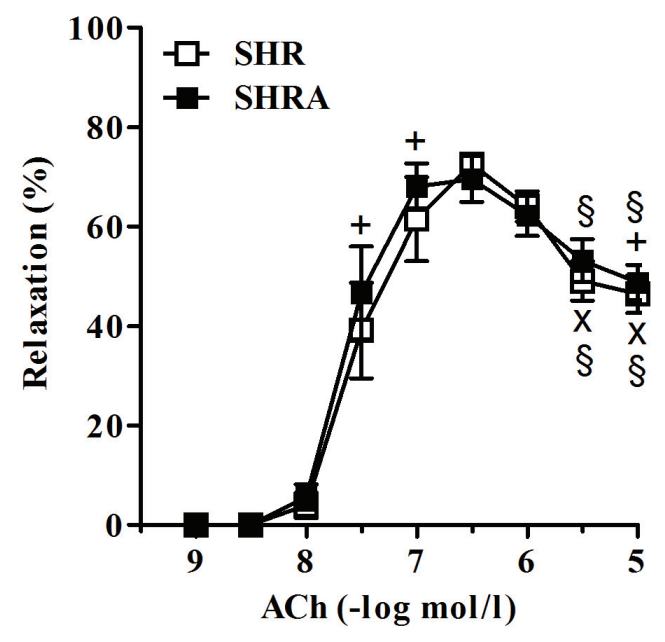

D

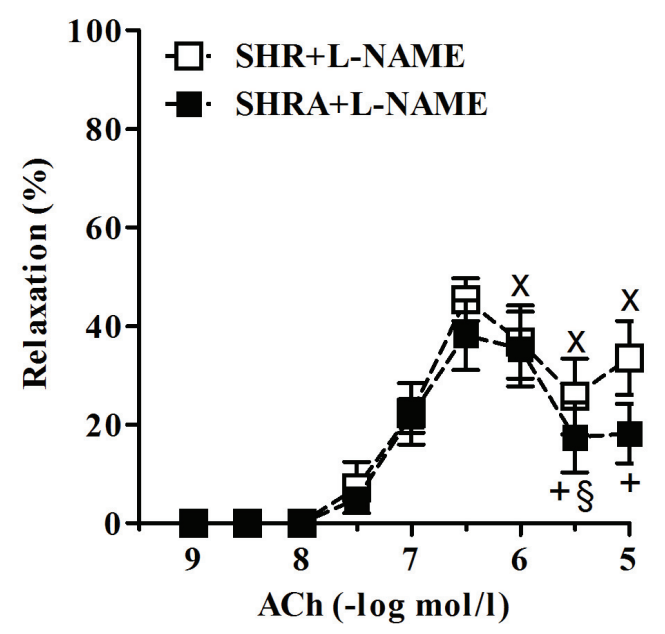

F

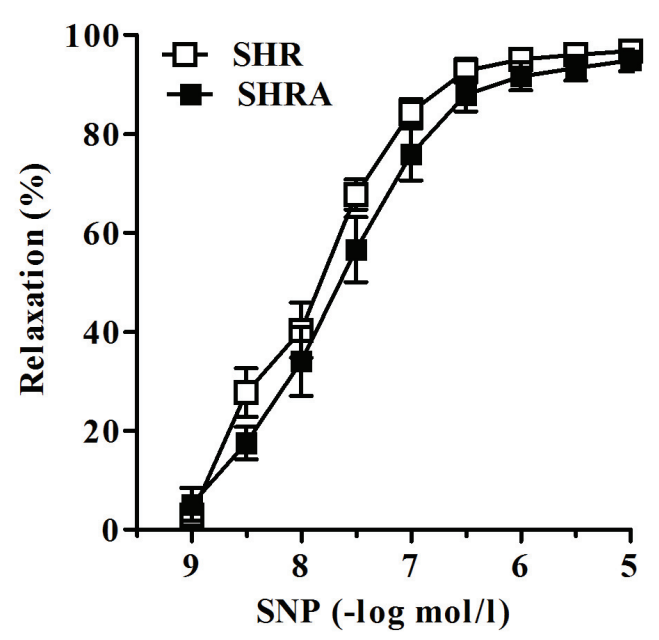

Fig. 3. Effect of AWE on relaxation of the femoral artery. A, B - ACh-induced relaxation, $\mathbf{C}, \mathbf{D}-\mathrm{ACh}$-induced relaxation after inhibition of nitric oxide production with L-NAME, E, F - SNP-induced relaxation. ACh - acetylcholine; AWE - Alibernet red wine extract; L-NAME - $N^{G}$-nitro-L-arginine methyl ester; SHR - spontaneously hypertensive rats; SHRA - AWE-treated SHR; SNP - sodium nitroprusside; WKY - Wistar-Kyoto rats; WKYA - AWE-treated WKY. Relaxation was determined in serotonin (1 4 mol/l)-precontracted artery segments. Values represent mean \pm S.E.M. of $n=6$ rats. $* p<0.05$ compared to respective control group, ${ }^{x} p<0.05$ compared to WKY control, ${ }^{+} p<0.05$ compared to WKYA, ${ }^{\S} p<0.05$ compared to maximal relaxation (ACh concentrations $0.3 \mu \mathrm{mol} / \mathrm{l}$ ) 


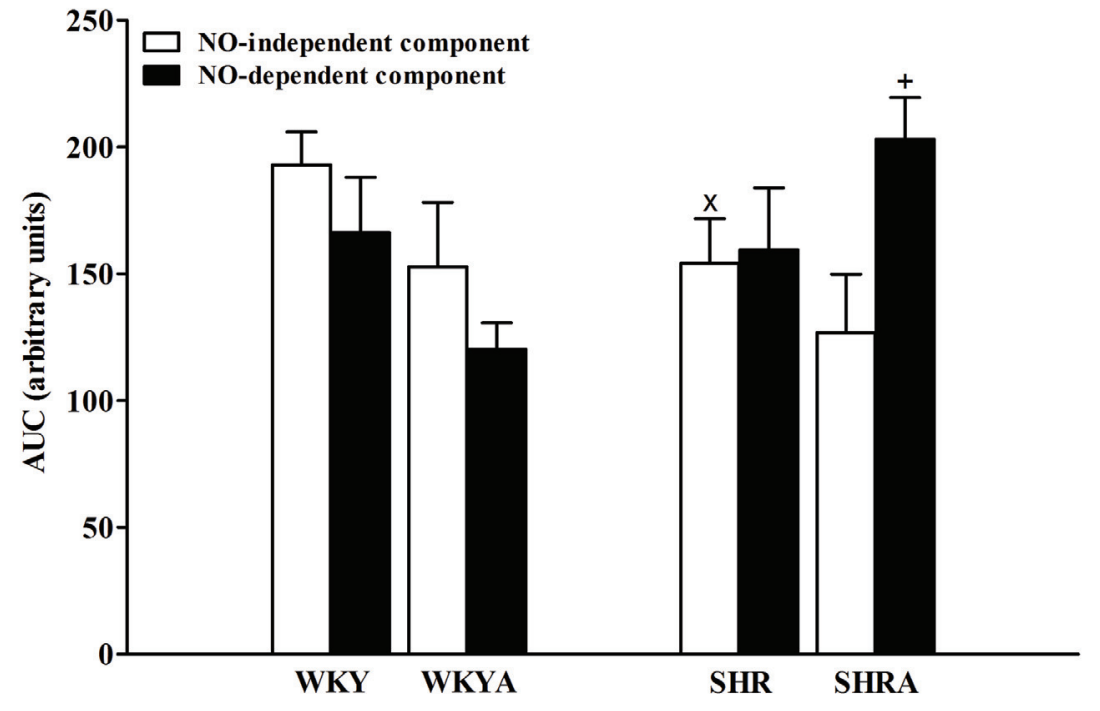

Fig. 4. Influence of AWE on NO-dependent and NO-independent components of acetylcholine-induced relaxations. AUC - area under the curve; AWE - Alibernet red wine extract; NO - nitric oxide; SHR spontaneously hypertensive rats; SHRA AWE-treated SHR; WKY - Wistar-Kyoto rats; WKYA - AWE-treated WKY. ${ }^{x} \mathrm{p}<0.05$ compared to WKY control, ${ }^{+} p<0.05$ compared to WKYA. Values represent mean \pm S.E.M. of $\mathrm{n}=6$ rats.
GPx activities (Rodrigo et al. 2005). Abovementioned data suggest that the antioxidant effect of RWC and/or red wine in rats without pathologies might result from direct scavenging properties of RWC. However, in conditions of elevated oxidative stress, as observed in diabetes (Udayakumar et al. 2010) or in experimental hypertension (Rush et al. 2007), both direct scavenging and activation of the antioxidant enzyme cascade may be involved in reducing oxidative damage. Thus antioxidant effects of red wine or RWC seem to be tissue specific and related to the oxidative status of the organism.

Another system involved in regulation of cardiovascular function that can be modified by RWC is the L-arginine/NO system. $\mathrm{NO}$ is well known to be involved in regulation of $\mathrm{BP}$ on both the central and peripheral level. In normotensive rats, reduction of NO led to hypertension, heart hypertrophy and fibrosis (Babál et al. 1997), reduced vasorelaxation and elevated vasoconstriction (Török and Kristek 2002). We observed that L-NAME-induced hypertension could be partially prevented by RWC by improving NO production (Pechánová et al. 2004). Activation of NO production or improvement of endothelium-dependent relaxation after red wine or RWC treatment was shown in the aorta of normotensive rats (Diebolt et al. 2001, Bernátová et al. 2002, Púzserová et al. 2006, Čačányiová et al. 2011) and mice (Chalopin et al. 2010), and in the porcine coronary artery (Ndiaye et al. 2005). In humans, red wine and RWC reduced BP and improved forearm endothelial function and NO production in young healthy individuals (Hamed et al. 2010). Similarly, a decrease of BP in association with elevation of plasma NO was seen after both red wine and RWC consumption in men at high cardiovascular risk (Chiva-Blanch et al. 2012). On the other hand, Andrade et al. (2009) observed increased flow-mediated dilatation after short-term red wine consumption only in hypercholesterolemic but not in hypertensive or healthy subjects. Additionally, no significant effect of red wine on BP (as compared to basal value) was seen in the same study (Andrade et al. 2009). It is thus of interest that in SHR, the most frequently used experimental model of human essential hypertension, only a few studies have been conducted so far to determine the effect of RWC on BP and/or vascular function.

López-Sepúlveda et al. (2008) found that 5-week treatment of SHR adult females with RWC $(40 \mathrm{mg} / \mathrm{kg} /$ day) reduced BP and improved endotheliumdependent relaxation of the aorta in association with reduction of superoxide. In our previous study, 8-week administration of RWC ( $20 \mathrm{mg} / \mathrm{kg} /$ day) to adult SHR males reduced BP and elevated vascular NO production in the aorta (Bernatova et al. 2007). Ten-week administration of a relatively high dosage of RWC $(100 \mathrm{mg} / \mathrm{kg} / \mathrm{day})$ was found to improve endotheliumdependent dilatation of the cerebral arterioles, normalize wall stress and diameter, and alter the systemic oxidative state, yet it failed to reduce BP (Chan et al. 2008).

Differences in the effect of RWC on BP in the above mentioned studies, both human and experimental, may result from several factors. Of particular importance are the differences in the composition of red wine polyphenols and in the dose and duration of treatment applied in individual studies. Secondly, sex and age can play a significant role in modulation of $\mathrm{BP}$ and endothelial (dys)function both in humans (Nilsson et al. 
2008, Kuneš et al. 2012) and in rats (Bernatova et al. 2009, Líšková et al. 2011, Kuneš et al. 2012).

Concerning the mechanism of ACh-induced relaxation, differences were found between normotensive and hypertensive rats. Several studies showed altered vascular acetylcholine-induced hyperpolarization and increased release of endothelium-derived constricting factors (EDCFs), including cyclooxygenase-generated prostaglandins, in the arteries of SHR at higher concentrations of ACh (Lüscher and Vanhoutte 1986, Fujii et al. 1993, Gündüz et al. 2011, Líšková et al. 2011). In the present study, we did not observe AChinduced release of EDCFs in WKY rats. We however observed that endothelial dysfunction in the femoral artery of young SHR may have been due to the release of EDCFs and/or reduced hyperpolarization (i.e. reduced NO-independent component of relaxation) rather than to lack of NO. In addition, 3-week administration of AWE failed to affect BP and endothelium-dependent and endothelium-independent relaxation of the femoral artery in both young WKY and SHR males. However, elevated NO synthesis and increased SOD activity found in AWEtreated SHR (Kondrashov et al. 2012) resulted in an increase of the NO-dependent component of relaxation (vs. AWE-treated WKY), presumably due to an increase in NO bioavailability. Furthermore, in WKY we did not see changes either in BP or in components of AChinduced relaxation, in accordance with no alterations in their NO production and SOD activity (Kondrashov et al. 2012).

In conclusion, short-term administration of the Slovak Alibernet red wine extract reduced lipid peroxidation in the left ventricle and liver of SHR and in the left ventricle of WKY rats. In spite of improved oxidative status, AWE failed to modulate vascular function and blood pressure in both young normotensive and hypertensive rats.

\section{Conflict of Interest}

There is no conflict of interest.

\section{Acknowledgements}

The authors thank Mrs. Jana Petova and Mrs. Maria Kovacsova for their technical assistance and for help with housing the animals. This study was partially supported by the Slovak Grant Agency for Science, grant No. 2/0084/10 and Slovak Research and Development Agency, grant No. APVV-0523-10 and APVV-0742-10.

\section{References}

AGOUNI A, LAGRUE-LAK-HAL AH, MOSTEFAI HA, TESSE A, MULDER P, ROUET P, DESMOULIN F, HEYMES C, MARTÍNEZ MC, ANDRIANTSITOHAINA R: Red wine polyphenols prevent metabolic and cardiovascular alterations associated with obesity in Zucker fatty rats (Fa/Fa). PLoS One 4: e5557, 2009. http://doi:10.1371/journal.pone.0005557

ANDRADE AC, CESENA FH, CONSOLIM-COLOMBO FM, COIMBRA SR, BENJÓ AM, KRIEGER EM, LUZ PL: Short-term red wine consumption promotes differential effects on plasma levels of high-density lipoprotein cholesterol, sympathetic activity, and endothelial function in hypercholesterolemic, hypertensive, and healthy subjects. Clinics (Sao Paulo) 64: 435-442, 2009.

BABÁL P, PECHÁNOVÁ O, BERNÁTOVÁ I, STVRTINA S: Chronic inhibition of NO synthesis produces myocardial fibrosis and arterial media hyperplasia. Histol Histopathol 12: 623-629, 1997.

BERNÁTOVÁ I, PECHÁNOVÁ O, BABÁL P, KYSELÁ S, STVRTINA S, ANDRIANTSITOHAINA R: Wine polyphenols improve cardiovascular remodeling and vascular function in NO-deficient hypertension. Am J Physiol 282: H942-H948, 2002.

BERNATOVA I, PUZSEROVA A, CSIZMADIOVA Z, ANDRIANTSITOHAINA R, ZEMAN M: Beneficial effect of red wine polyphenols on blood pressure of chronic social stress-exposed hypertensive rats. In: Proceedings of Genetic and Environmental Factors in Hypertension 2007. BERNÁTOVÁ I (ed), Institute of Normal and Pathological Physiology SAS, Bratislava, 2007, pp 23-28.

BERNATOVA I, CONDE MV, KOPINCOVA J, GONZÁLEZ MC, PUZSEROVA A, ARRIBAS SM: Endothelial dysfunction in spontaneously hypertensive rats: focus on methodological aspects. J Hypertens Suppl 27: S27S31, 2009. 
BORNHOEFT J, CASTANEDA D, NEMOSECK T, WANG P, HENNING SM, HONG MY: The protective effects of green tea polyphenols: lipid profile, inflammation, and antioxidant capacity in rats fed an atherogenic diet and dextran sodium sulfate. $J$ Med Food 15: 726-732, 2012.

ČAČÁNYIOVÁ S, PECHÁŇOVÁ O, BABÁL P, ČERNÁ A, JANEGA P, ANDRIANTSITOHAINA R: Red wine polyphenols correct vascular function injured by chronic carbon tetrachloride intoxication. Gen Physiol Biophys 30: 207-213, 2011.

CAROLLO C, PRESTI LR, CAIMI G: Wine, diet, and arterial hypertension. Angiology 58: 92-96, 2007.

CHALOPIN M, TESSE A, MARTÍNEZ MC, ROGNAN D, ARNAL JF, ANDRIANTSITOHAINA R: Estrogen receptor alpha as a key target of red wine polyphenols action on the endothelium. PLoS One 5: e8554, 2010. http://doi:10.1371/journal.pone.0008554

CHAN SL, TABELLION A, BAGREL D, PERRIN-SARRADO C, CAPDEVILLE-ATKINSON C, ATKINSON J: Impact of chronic treatment with red wine polyphenols (RWP) on cerebral arterioles in the spontaneous hypertensive rat. J Cardiovasc Pharmacol 51: 304-310, 2008.

CHIVA-BLANCH G, URPI-SARDA M, ROS E, ARRANZ S, VALDERAS-MARTÍNEZ P, CASAS R, SACANELLA E, LLORACH R, LAMUELA-RAVENTOS RM, ANDRES-LACUEVA C, ESTRUCH R: Dealcoholized red wine decreases systolic and diastolic blood pressure and increases plasma nitric oxide: short communication. Circ Res 111: 1065-1068, 2012.

COSTANZO S, Di CASTELnUOVO A, DONATI MB, IACOVIELlO L, DE GAETANO G: Wine, beer or spirit drinking in relation to fatal and non-fatal cardiovascular events: a meta-analysis. Eur J Epidemiol 26: 833-850, 2011.

DEMROW HS, SLANE PR, FOLTS JD: Administration of wine and grape juice inhibits in vivo platelet activity and thrombosis in stenosed canine coronary arteries. Circulation 91: 1182-1188, 1995.

DIEBOLT M, BUCHER B, ANDRIANTSITOHAINA R: Wine polyphenols decrease blood pressure, improve NO vasodilatation, and induce gene expression. Hypertension 38: 159-165, 2001.

FERNÁNDEZ-PACHÓN MS, BERNÁ G, OTAOLAURRUCHI E, TRONCOSO AM, MARTÍN F, GARCÍAPARRILLA M: Changes in antioxidant endogenous enzymes (activity and gene expression levels) after repeated red wine intake. J Agric Food Chem 57: 6578-6583, 2009.

FUJII K, OHMORI S, TOMINAGA M, ABE I, TAKATA Y, OHYA Y, KOBAYASHI K, FUJISHIMA M: Agerelated changes in endothelium-dependent hyperpolarization in the rat mesenteric artery. Am J Physiol 265 : H509-H516, 1993.

GÜNDÜZ F, KOÇER G, ULKER S, MEISELMAN HJ, BAŞKURT OK, SENTÜRK UK: Exercise training enhances flow-mediated dilation in spontaneously hypertensive rats. Physiol Res 60: 589-597, 2011.

HAMED S, ALSHIEK J, AHARON A, BRENNER B, ROGUIN A: Red wine consumption improves in vitro migration of endothelial progenitor cells in young, healthy individuals. Am J Clin Nutr 92: 161-169, 2010.

HANSEN AS, MARCKMANN P, DRAGSTED LO, FINNÉ NIELSEN IL, NIELSEN SE, GRONBAEK M: Effect of red wine and red grape extract on blood lipids, haemostatic factors, and other risk factors for cardiovascular disease. Eur J Clin Nutr 59: 449-455, 2005.

HERTOG MG, KROMHOUT D, ARAVANIS C, BLACKBURN H, BUZINA R, FIDANZA F, GIAMPAOLI S, JANSEN A, MENOTTI A, NEDELJKOVIC S, PEKKARINEN M, SIMIC BS, TOSHIMA H, FESKENS EJM, HOLLMAN PCH, KATAN MB: Flavonoid intake and long-term risk of coronary heart disease and cancer in the seven countries study. Arch Intern Med 155: 381-386, 1995.

HU ML, FRANKEL EN, LEIBOVITZ BE, TAPPEL AL: Effect of dietary lipids and vitamin E on in vitro lipid peroxidation in rat liver and kidney homogenates. $J$ Nutr 119: 1574-1582, 1989.

JIMÉNEZ R, LÓPEZ-SEPÚlVEDA R, KADMIRI M, ROMERO M, VERA R, SÁNCHEZ M, VARGAS F, O'VALlE F, ZARZUELO A, DUENAS M, SANTOS-BUELGA C, DUARTE J: Polyphenols restore endothelial function in DOCA-salt hypertension: role of endothelin-1 and NADPH oxidase. Free Radic Biol Med 43: 462-473, 2007. 
KONDRASHOV A, VRANKOVÁ S, DOVINOVÁ I, ŠEVČÍK R, PAROHOVÁ J, BARTA A, PECHÁŇOVÁ O, KOVACSOVÁ M: The effects of new Alibernet red wine extract on nitric oxide and reactive oxygen species production in spontaneously hypertensive rats. Oxid Med Cell Longev 2012: 806285, 2012. http://doi: $10.1155 / 2012 / 806285$

KUNEŠ J, KADLECOVÁ M, VANĚČKOVÁ I, ZICHA J: Critical developmental periods in the pathogenesis of hypertension. Physiol Res 61 (Suppl 1): S9-S17, 2012.

LIONETTO MG, GIORDANO ME, CALISI A, ERROI E, DE NUCCIO F, SCHETTINO T: Effect of the daily ingestion of a purified anthocyanin extract from grape skin on rat serum antioxidant capacity. Physiol Res 60: 637-645, 2011.

LÍŠKOVÁ S, PETROVÁ M, KAREN P, KUNEŠ J, ZICHA J: Effects of aging and hypertension on the participation of endothelium-derived constricting factor (EDCF) in norepinephrine-induced contraction of rat femoral artery. Eur J Pharmacol 667: 265-270, 2011.

LÓPEZ-SEPÚLVEDA R, JIMÉNEZ R, ROMERO M, ZARZUELO MJ, SÁNCHEZ M, GÓMEZ-GUZMÁN M, VARGAS F, O'VALLE F, ZARZUELO A, PÉREZ-VIZCANÍO F, DUARTE J: Wine polyphenols improve endothelial function in large vessels of female spontaneously hypertensive rats. Hypertension 51: 1088-1095, 2008.

LÜSCHER TF, VANHOUTTE PM: Endothelium-dependent contractions to acetylcholine in the aorta of the spontaneously hypertensive rat. Hypertension 8: 344-348, 1986.

MULVANY MJ, HALPERN W: Contractile properties of small arterial resistance vessels in spontaneously hypertensive and normotensive rats. Circ Res 41: 19-26, 1977.

NDIAYE M, CHATAIGNEAU M, LOBYSHEVA I, CHATAIGNEAU T, SCHINI-KERTH VB: Red wine polyphenol-induced, endothelium-dependent NO-mediated relaxation is due to the redox-sensitive PI3kinase/Akt-dependent phosphorylation of endothelial NO-synthase in the isolated porcine coronary artery. FASEB J 19: 455-457, 2005.

NIGDIKAR SV, WILLIAMS NR, GRIFFIN BA, HOWARD AN: Consumption of red wine polyphenols reduces the susceptibility of low-density lipoproteins to oxidation in vivo. Am J Clin Nutr 68: 258-265, 1998.

NILSSON PM, LURBE E, LAURENT S: The early life origins of vascular ageing and cardiovascular risk: the EVA syndrome. J Hypertens 26: 1049-1057, 2008.

NOGUER MA, CEREZO AB, DONOSO NAVARRO E, GARCIA-PARRILLA MC: Intake of alcohol-free red wine modulates antioxidant enzyme activities in a human intervention study. Pharmacol Res 65: 609-614, 2012.

PECHÁNOVÁ O, BERNÁTOVÁ I, BABÁL P, MARTÍNEZ MC, KYSELÁ S, STVRTINA S, ANDRIANTSITOHAINA R: Red wine polyphenols prevent cardiovascular alterations in L-NAME-induced hypertension. J Hypertens 22: 1551-1559, 2004.

PILŠÁKOVÁ L, RIEČANSKÝ I, JAGLA F: The physiological actions of isoflavone phytoestrogens. Physiol Res 59: 651-664, 2010.

PINTÉROVÁ M, KUNEŠ J, ZICHA J: Altered neural and vascular mechanisms in hypertension. Physiol Res 60: 381402, 2011.

PÚZSEROVÁ A, CSIZMADIOVÁ Z, ANDRIANTSITOHAINA R, BERNÁTOVÁ I: Vascular effects of red wine polyphenols in chronic stress-exposed Wistar-Kyoto rats. Physiol Res 55: 39-47, 2006.

PUZSEROVA A, SLEZAK P, BALIS P, BERNATOVA I: Long-term social stress induces nitric oxide-independent endothelial dysfunction in normotensive rats. Stress 16: 331-339, 2013.

RAMASSAMY C: Emerging role of polyphenolic compounds in the treatment of neurodegenerative diseases: a review of their intracellular targets. Eur J Pharmacol 545: 51-64, 2006.

RENAUD SC, GUÉGUEN R, CONARD P, LANZMANN-PETITHORY D, ORGOGOZO JM, HENRY O: Moderate wine drinkers have lower hypertension-related mortality: a prospective cohort study in French men. Am J Clin Nutr 80: 621-625, 2004.

RETTERSTOL L, BERGE KE, BRAATEN Ø, EIKVAR L, PEDERSEN TR, SANDVIK L: A daily glass of red wine: does it affect markers of inflammation? Alcohol Alcohol 40: 102-105, 2005.

RODRIGO R, CASTILLO R, CARRASCO R, HUERTA P, MORENO M: Diminution of tissue lipid peroxidation in rats is related to the in vitro antioxidant capacity of wine. Life Sci 76: 889-900, 2005. 
RUSH JW, QUADRILATERO J, LEVY AS, FORD RJ: Chronic resveratrol enhances endothelium-dependent relaxation but does not alter eNOS levels in aorta of spontaneously hypertensive rats. Exp Biol Med (Maywood) 232: 814-822, 2007.

SATO M, RAMARATHNAM N, SUZUKI Y, OHKUBO T, TAKEUCHI M, OCHI H: Varietal differences in the phenolic content and superoxide radical scavenging potential of wines from different sources. J Agric Food Chem 44: 37-41, 1996.

SCOLA G, CONTE D, SPADA PW, DANI C, VANDERLINDE R, FUNCHAL C, SALVADOR M: Flavan-3-ol compounds from wine wastes with in vitro and in vivo antioxidant activity. Nutrients 2: 1048-1059, 2010.

SPANIER G, XU H, XIA N, TOBIAS S, DENG S, WOJNOWSKI L, FORSTERMANN U, LI H: Resveratrol reduces endothelial oxidative stress by modulating the gene expression of superoxide dismutase 1 (SOD1), glutathione peroxidase 1 (GPx1) and NADPH oxidase subunit (Nox4). J Physiol Pharmacol 60: 111-116, 2009.

STEIN JH, KEEVIL JG, WIEBE DA, AESCHLIMANN S, FOLTS JD: Purple grape juice improves endothelial function and reduces the susceptibility of LDL cholesterol to oxidation in patients with coronary artery disease. Circulation 100: 1050-1055, 1999.

TÖRÖK J, KRISTEK F: Beneficial effect of pentaerythrityl tetranitrate on functional and morphological changes in the rat thoracic aorta evoked by long-term nitric oxide synthase inhibition. Vascul Pharmacol 38: 177-182, 2002.

UDAYAKUMAR R, KASTHURIRENGAN S, VASUDEVAN A, MARIASHIBU TS, RAYAN JJ, CHOI CW, GANAPATHI A, KIM SC: Antioxidant effect of dietary supplement Withania somnifera L. reduce blood glucose levels in alloxan-induced diabetic rats. Plant Foods Hum Nutr 65: 91-98, 2010.

ZOU JG, WANG ZR, HUANG YZ, CAO KJ, WU JM: Effect of red wine and wine polyphenol resveratrol on endothelial function in hypercholesterolemic rabbits. Int J Mol Med 11: 317-320, 2003. 